\title{
Expression and integration of a foreign gene in orange (Citrus sinensis Osb.) protoplasts by direct DNA transfer ${ }^{1)}$
}

\author{
Shozo KobayaShI* and Hirofumi UCHIMIYA** \\ *Akitsu Branch, Fruit Tree Research Station, Akitsu, Hiroshima 729-24 \\ **Institute of Biological Sciences, University of Tsukuba, \\ Tsukuba City, Ibaraki 305
}

(Received 28 November 1988)

\begin{abstract}
Protoplasts isolated from suspension cultured cells of orange (Citrus sinensis Osb.) were treated with a bacterial plasmid DNA carrying a chimeric gene consisting of the nopaline synthase promoter, the aminoglycoside phosphotransferase II [APH( $\left.3^{\prime}\right)$ II] structural gene from the bacterial transposon Tn 5 and a terminator region from cauliflower mosaic virus DNA. Colonies capable of proliferating in a medium containing kanamycin $(25 \mu \mathrm{g} / \mathrm{ml})$ possessed APH(3')II activity and an intact foreign gene. The transformation frequency was recorded to be in the order of $10^{-6}$.
\end{abstract}

\section{INTRODUCTION}

The recent progress in techniques for the manipulation of isolated protoplasts has made possible not only the production of somatic hydrid plants, but also the transfer of foreign DNA directly into plant protoplasts (Davey et al., 1980 ; Krens et al., 1982). The application of these techniques to citrus would be of great value for the improvement of this kind of fruit tree. Vardi et al. (1982) and we (Kobayashi et al., 1983) reported plant regeneration from orange protoplasts, and we demonstrated the uniformity of citrus protoclones (Kobayashi, 1987). This citrus protoplast culture system has been successfully employed in producing somatic hydrid plants (Ohgawara et al., 1985; Kobayashi et al., 1988) and cybrid plants (Vardi et al., 1987). As an alternative means of genetic modification of citrus protoplasts, we have attempted to produce transformants by direct DNA transfer.

Here we report the transfer of foreign DNA into orange protoplasts, and the stable expression and presence of a foreign gene in the cultured cells.

\section{MATERIALS AND METHODS}

Plant materials and protoplast isolation

Suspension cultured cells of 'Trovita' orange (Citrus sinensis Osb.) which

1) Contribution No. Fruit Tree Res. Stn.: E-116. 
originated from nucellus tissues were maintained in a Murashige and Tucker [MT] (1969) liquid medium supplemented with $10 \mathrm{mg} / \mathrm{l}$ 6-benzylaminopurine [BA] as described earlier (Kobayashi et al., 1985). Two-week-old cells were transferred to a hormone-free MT liquid medium (denoted to MT basal medium). After culturing in the same medium for 2 weeks, the cells were collected and subjected to protoplast isolation using the procedure described earlier (Kobayashi et al., 1985).

\section{DNA transfer}

The method employed for DNA transformation was basically a modiffication of the method of Krens et al. (1982) and Paszkowski et al. (1984). Briefly, $0.9 \mathrm{ml}$ protoplasts $\left(2.2 \times 10^{6}\right)$, suspended in $0.6 \mathrm{M}$ mannitol, were mixed with a $0.1 \mathrm{ml}$ DNA solution containing $10 \mu \mathrm{g}$ of the circular form of the bacterial plasmid pCT2T3, which contained the selectable marker gene [aminoglycosidephosphotransferase II : APH $\left(3^{\prime}\right)$ II] (Morota and Uchimiya, 1987; Uchimiya et al., 1986b). The plasmid was prepared without RNase treatment according to the method of Birnboim and Doly (1979).

After $5 \mathrm{~min}$, a $0.5 \mathrm{ml}$ solution of $40 \%$ (w/v) polyethylene glycol 6,000 , dissolved in a $\mathrm{F}$ medium (Krens et al., 1982), was added to the protoplast-DNA mixture. After $30 \mathrm{~min}$, the incubation mixture was diluted with an equal volume of a $\mathrm{F}$ medium, with an osmotic value adjusted to $790 \mathrm{mosmol} / \mathrm{kg} \cdot \mathrm{H}_{2} \mathrm{O}$ by additional glucose. A similar stepwise dilution was performed three times every $10 \mathrm{~min}$.

\section{Protoplast culture and selection of transformants}

Protoplasts $\left(10^{5} / \mathrm{ml}\right)$ were cultured in a $3 \mathrm{ml}$ medium, which consisted of a MT basal medium containing $0.35 \mathrm{M}$ mannitol in a Falcon Petri dish $(60 \times 15 \mathrm{~mm})$. The plates were sealed with Parafilm, and maintained under $16 \mathrm{~h} /$ day illumination with a cool fluorescent light (500 lux) at $26^{\circ} \mathrm{C}$. After 2 weeks, the medium was diluted with an equal volume of a MT basal medium supplemented with $0.25 \mathrm{M}$ mannitol. After 2 weeks, the medium was solidified by an equal volume of a MT basal medium supplemented with $0.25 \mathrm{M}$ mannitol, $50 \mathrm{mg} /$ kanamycin sulfate (Meiji Seika Co., Tokyo, Japan) and $1.2 \%$ agarose (Sea Plaque, LMT, Marine Colloids, USA). After 2 months, colonies sustaining cell division under these conditions were transferred onto a MT basal medium containing $0.8 \%$ Bacto-agar and $25 \mu \mathrm{g} / \mathrm{ml}$ kanamycin sulfate for the second selection.

\section{DNA analysis}

DNAs were extracted from the callus according to the method of Rogers et al. (1985). Ten micrograms DNA digested with $E c o$ RI and $B g l \mathrm{II}$ were subjected to agarose gel electrophoresis. After electrophoresis, the gel was treated with alkali, then blotted to a nitrocellulose filter. The dried filter was hybridized with biotin-labelled probe DNA. DNA fragments [ $2 \mathrm{~kb} E c o R I-B g l \mathrm{II}$, containing the 
APH(3')II gene] prepared from plasmid pCT2T3 were used as the probe. Biotinlabelling of the probe DNA was carried out using biotin-11-dUTP and a nicktranslation reagent kit (Bethesda Res. Labs. Inc., USA). Visualization of the probe-target DNA hybrid was carried out using streptavidin-alkaline phosphatase conjugate, nitro blue tetrazolium (NBT) and 5-bromo-4-chloro-3-indolylphosphate, p-toluidine salt (BCIP).

\section{$A P H\left(\Im^{\prime}\right) I I$ assay}

The analysis of APH( $\left.3^{\prime}\right)$ II was carried out according to the methods of Reiss et al. (1984) and Schreier et al. (1985).

\section{RESULTS AND DISCUSSION}

The plating efficiency of orange protoplasts was approximately $20 \%$ in the medium used. No colony was produced in the control cultures where protoplasts, not treated with DNA, were maintained under the selective conditions. Ten colonies, of the size greater than $1 \mathrm{~mm}$, were obtained from $9 \times 10^{5} \mathrm{DNA}$-treated protoplasts by the first selection (Fig. 1). Upon transferring those colonies to the second kanamycin-containing medium, 8 colonies survived and increased their size. Then, these clones were transferred onto a kanamycin-free MT basal medium supplemented with $5 \mathrm{mg} / \mathrm{BA}$ and $0.8 \%$ agar. After subculture for 6 months, DNAs isolated from 8 such clones were tested by Southern hydridization with a probe containing a chimeric APH(3')II gene [ $2 \mathrm{~kb} E c o$ RI-BalII fragment of

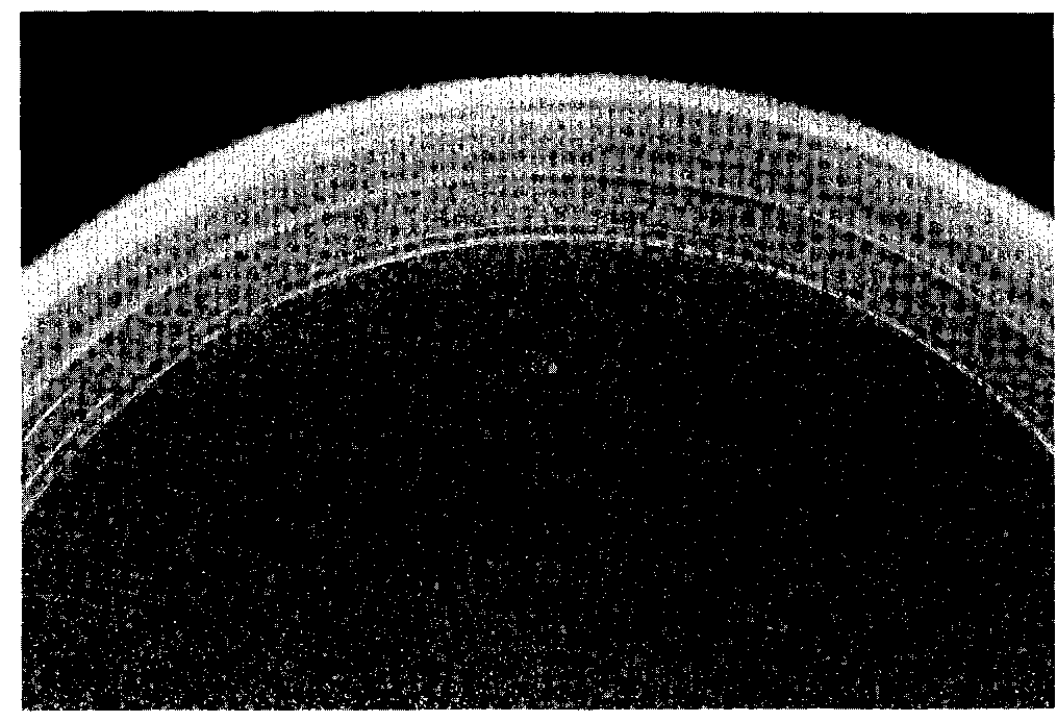

Fig. 1. A colony derived from DNA-treated citrus protoplasts after first selection. Kanamycin sulfate $(25 \mu \mathrm{g} / \mathrm{ml})$ was added to the agar solidified medium. 


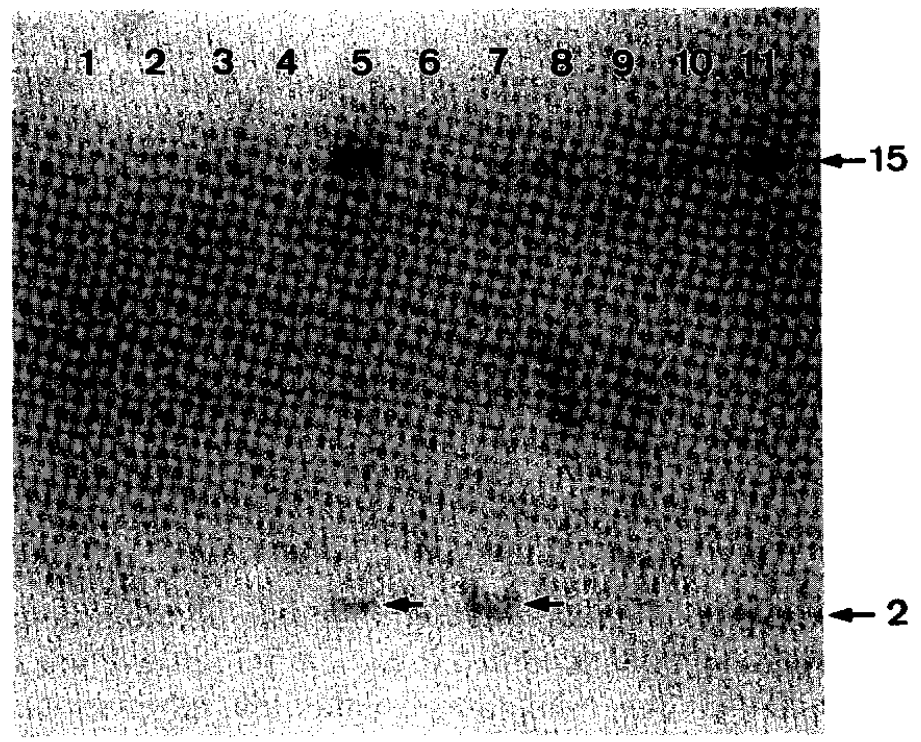

Fig. 2. Southern blot analysis of DNA from kanamycin-resistant clones. A sample of 10 micrograms DNA digested with EcoRI-BglII was loaded on each track. The probe was the EcoRI-BglII $2 \mathrm{~kb}$ fragments of pCT2T3 (Morota and Uchimiya, 1987; Uchimiya et al. 1986b) containing the APH(3')II gene. Lane 1, control; lanes 2-9, kanamycin-resistant clones, R1, R2, R4, R5, R6, R7, R8, and R10, respectively; lanes 10 and 11,20 picograms and 100 picograms, respectively, of pCT2T3. The numerals indicate $\mathrm{kbp}$.

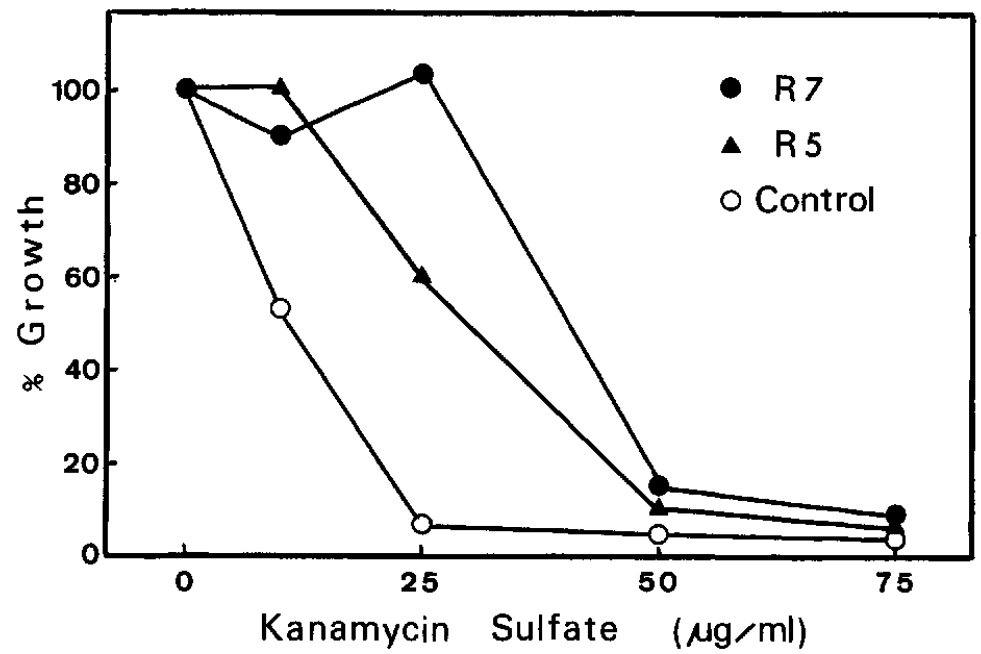

Fig. 3. Growth response of control callus and that of transformed clones to kanamycin. About $30 \mathrm{mg}$ 8-month-old calli, which subcultured on a kanamycin-free medium, were cultured on the medium containing various concentrations of kanamycin sulfate. The fresh weight was recorded after 2 months. The $\%$ growth is the percentage increase in the fresh weight of a callus grown on a medium containing kanamycin sulfate at a given concentration as compared to the weight of a callus grown on a medium lacking kanamycin sulfate. 
pCT2T3]. An intact $2 \mathrm{~kb}$ fragment containing the chimeric APH( $\left.3^{\prime}\right) \mathrm{II}$ gene was detected in 2 clones (R5 and R7) (Fig. 2). The other DNA fragment (15 kb) homologous to the probe DNA was also detected in the clone R5, and slightly in clones R1, R2 and R8. DNAs from clones R4, R6, R10 and those from control callus did not show such a hybridization signal (Fig. 2). This finding shows that the clones R5 and R7 are transformant. However, it is not clear whether or not the other clones R1, R2 and R8 are also transformant. The transformed clones R5 and R7 were tolerant to exogenous kanamycin until the concentration of $25 \mu \mathrm{g} /$ ml (Fig. 3). The APH(3')II enzyme activity was detected in the clone R7 (Fig. 4), but not in the clone R5. The clone R5 probably does not produce a detectable amount of the enzyme.

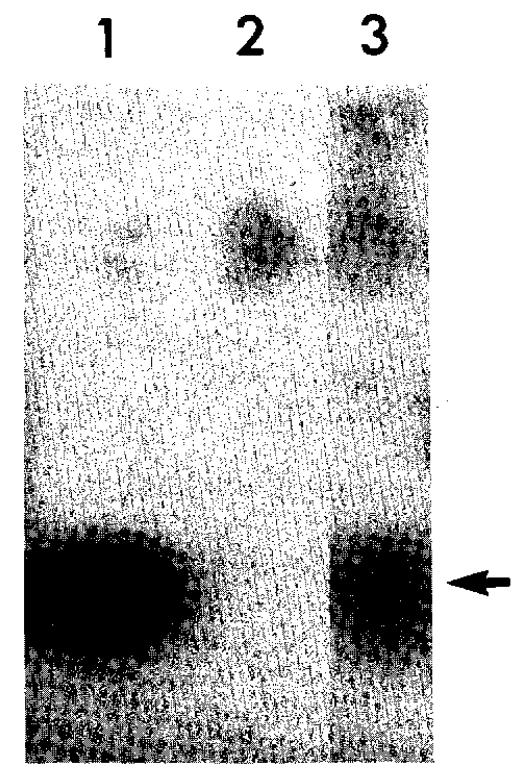

Fig. 4. APH(3')II activity analysis. Lane 1, kanamycin-resistant Oryza sativa transformed cells T14 (Uchimiya et al., 1986b); lane 2, control; lane 3, kanamycinresistant $R 7$ clone. The arrow indicates the position of APH(3')II enzyme.

DNA-mediated transformation using protoplasts has been reported for dicotyledonous plants such as moth bean (Köhler et al., 1987) and tobacco (Paszkowski et al., 1984; Uchimiya et al., 1986a), and for graminaceous monocots including Italian Ryegrass (Potrykus et al., 1985), maize (Fromm et al., 1986), rice (Uchimiya et al., 1986b), sugarcane (Chen et al., 1987) and one-grained wheat (Lörz et al., 1985). In woody plants, however, DNA-mediated transformation has not yet been reported. In this report, we demonstrated that protoplasts of fruit tree Citrus sinensis could be transformed through direct DNA transfer. Regeneration of whole plant from such cell line will be needed in order to facilitate genetic manipulation of citrus. 
This research was supported in part by Grant-in-Aid for Science Research from Ministry of Education, Science and Culture of Japan. We wish to thank Dr. S. R. Sykes for reading the manuscript.

\section{REFERENCES}

BIRNBoIM, H. C. and DoLy, J. (1979) A rapid alkaline extraction procedure for screening recombinant plasmid DNA. Nucleic Acids Res. 7, 1513-1523.

Chen, W. H., Gartland, K. M. A., Davey, M. R., Sotak, R., Gartland, J. S., Mulligan, J. B., Power, J. B and Cocking, E. C. (1987) Transformation of sugarcane protoplast by direct uptake of a selectable chimaeric gene. Plant Cell Reports 6, 297-301.

Davey, M. R., Cocking, E. C., Freeman, J., Pearce, N. and Tudor, I. (1980) Transformation of Petunia protoplasts by isolated Agrobacterium plasmids. Plant Sci. Lett. 18, 307-313.

Fromm, M. E., TAYLOR, L. P. and WALBOT, V. (1986) Stable transformation of maize after gene transfer by electroporation. Nature 319, 791-793.

KoBayashi, S., UChImIYA, H. and IKEDA, I. (1983) Plant regeneration from 'Trovita' orange protoplasts. Japan. J. Breed. 33, 119-122.

KoBaYASHI, S., IKEDA, I. and UCHIMIYA, H. (1985) Conditions for high frequency embryogenesis from orange (Citrus sinensis Osb.) protoplasts. Plant Cell Tissue Organ Culture 4, 249-259.

KoBAYASHI, S. (1987) Uniformity of plants regenerated from orange (Citrus sinensis Osb.) Protoplasts. Theor. Appl. Genet. 74, 10-14.

Kobayashi, S., Ohgawara, T., Ohgawara, E., Oiyama, I. and Ishil, S. (1988) A somatic hybrid plant obtained by protoplast fusion between navel orange (Citrus sinensis) and satsuma mandarin (C. unshiu). Plant Cell Tissue Organ Culture 14, 63-69.

KöHLER, F., Golz, C., EAPEN, S., KoHN, H. and SCHIEDER, O. (1987) Stable transformation of moth bean Vigna aconitifolia via direct gene transfer. Plant Cell Reports 6, 313-317.

Krens, F. A., MolendiJK, L., Wullems, G. J. and SchilPERoort, R. A. (1982) In vitro transformation of plant protoplasts with Ti-plasmid DNA. Nature 296, 72-74.

LŐRZ, H., BAKER, B. and SCHELL, J. (1985) Gene transfer to cereal cells mediated by protoplast transformation. Mol. Gen. Genet. 199, 178-182.

Morota, H. and UсhimiYa, H. (1987) Stable maintenance of foreign DNA in transformed cell lines of rice (Oryza sativa L.). Jpm. J. Genet. 62, 363-368.

MuRASHIGE, T. and TUCKER, D. P. H. (1969) Growth factor requirements of citrus tissue culture. In: Proc. 1st Int. Citrus Symp., Vol. 3 (ed: H. D. Chapman), pp. 1155-1161. Univ. Calif., Riverside.

Ohgawar, T., Kobayashi, S., OHgawara, E., UchimiYa, H. and Ishi, S. (1985) Somatic hybrid plants obtained by protoplast fusion between Citrus sinensis and Poncirus trifoliata. Theor. Appl. Genet. 71, 1-4.

Paszkowski, J., Schillito, R, D., Saul, M., Mandak, V., Hohn, T., Hohn, B. and Potrykus, I. (1984) Direct gene transfer to plants. EMBO J. 3, 2717-2722.

Potrykus, I., Saul, M. W., Petruska, J., Paszkowski, J. and Shillito, R. D. (1985) Direct gene transfer to cells of a graminaceous monocot. Mol. Gen. Genet. 199, 183-188.

Reiss, B., Sprengel, R., Will, H. and Schaller, H. (1984) A new sensitive method for qualitative and quantitative assay of neomycin phosphotransferase in crude cell extracts. Gene 30, 211-218.

ROGERS, S. O. and BENDICH, A. J. (1985) Extraction of DNA from milligram amounts of fresh, herbarium and mummified plant tissues. Plant Mol. Biol. 5, 69-76.

Schreier, P. H., Seftor, E. A., Schell, J. and BohnerT, H. J. (1985) The use of nuclear-encoded sequences to direct the light-regulated synthesis and transport of a foreign protein into plant chloroplasts. EMBO J. 4, 25-32. 
Uchimiya, H., Hirochika, H., Hashimoto, H., hara, A., Masuda, T., Kasumimoto, T., Harada, H., IKEDA, J. E. and YoshIOKA, M. (1986a) Co-expression and inheritance of foreign genes in transformants obtained by direct DNA transformations of tobacco protoplasts. Mol. Gen. Genet. 205, 1-8.

Uchimiya, H., Fushimi, T., Hashimoto, H., Harada, H., Syono, K. and Sugawara, Y. (1986b) Expression of a foreign gene in callus derived from DNA-treated protoplasts of rice (Oryza sati$v a$ L.). Mol. Gen. Genet. 204, 204-207.

VARDI, A., SPIEgel-Roy, P. and GALUN, E. (1982) Plant regeneration from citrus protoplasts: variability in methodological requirements among cultivars and species. Theor. Appl. Genet. 62, 171-176.

VARDI, A., BREIMAN, A. and GALUN, E. (1987) Citrus cybrids: production by donor-recipient protoplast-fusion and verification by mitochondrial-DNA restriction profiles. Theor. Appl. Genet. 75, 51-58. 